\title{
Pengolahan Pascapanen pada Tanaman Kakao untuk Meningkatkan Mutu Biji Kakao : Review
}

Arya Bima Senna ${ }^{1 *}$

${ }^{1}$ Balai Pengkajian Teknologi Pertanian Papua Barat

\begin{tabular}{l}
\hline \multicolumn{1}{c}{ ARTIKEL INFO } \\
\hline Sejarah artikel \\
Diterima $04 / 11 / 2020$ \\
Diterima dalam bentuk revisi 12/12/2020 \\
Diterima dan disetujui 17/12/2020 \\
Tersedia online 23/12/2020 \\
\hline Kata kunci \\
Biji kakao \\
Fermentasi \\
Kakao \\
Pascapanen \\
\hline
\end{tabular}
\begin{abstract}
ABSTRAK
Pascapanen dalam budidaya berguna sebagai pascapanen merupakan salah satu aspek penting dalam penjualan hasil tanaman kakao. Harga jual biji kakao sangatlah beragam tergantung juga dari pengepul. Ada juga dibeberapa daerah membentuk koperasi petani sehingga hasil dari panen petani dapat dikoordinir dalam satu koperasi yang menyebabkan harga yang terkontrol dan lebih jelas, karena ada standar yang sudah ditetapkan petani menjual dari biji kakao basah, biji kakao kering belum terfermentasi, biji kakao kering sudah terfermentasi. Dalam prakteknya pascapanen meliputi sortasi, pembelahan buah, fermentasi, perendaman dan pencucian, pengeringan, penggudangan. Pengolahan pascapanen pada tanaman kakao untuk meningkatkan kualitas dari hasil panen kakao yang dimiliki oleh petani. Biji yang telah melalui fermentasi akan meningkatkan cita rasa ketika biji kakao diolah. Biji kakao yang melalui dalam proses pengolahan pascapanen akan lebih lama disimpan dan tidak akan mengurangi kualitas dari biji kakao. Biji kakao yang difermentasi mengandung air didalamnya yang berfungsi selama fermentasi untuk proses reaksi enzima pada biji serta untuk pertumbuhan mikroba pada pulp kakao. Kakao yang telah mengalami proses pasca panen inilah yang memiliki nilai jual yang tinggi sehingga akan meningkatkan pendapatan petani. Ada juga dibeberapa daerah membentuk koperasi petani sehingga hasil dari panen petani dapat di koordinir dalam satu koperasi yang menyebabkan harga yang terkontrol dan lebih jelas, karena ada standar yang sudah ditetapkan petani menjual dari biji kakao basah, biji kakao kering belum terfermentasi, biji kakao kering sudah terfermentasi.
\end{abstract}

C 2020 Politeknik Pembangunan Pertanian Manokwari 


\section{ABSTRACT}

Postharvest in cultivation is useful as postharvest and is an important aspect in selling cocoa crops. The selling price of cocoa beans varies greatly depending on the collectors. There are also some areas forming farmer cooperatives so that the results of farmers' harvests can be coordinated in one cooperative which results in clearer and controlled prices, because there are standards that have been set by farmers to sell wet cocoa beans, dry cocoa beans have not been fermented, dry cocoa beans are fermented. Post-harvest practice includes sorting, fruit splitting, fermentation, soaking and washing, drying, and warehousing. Post-harvest processing of cocoa plants to improve the quality of the cocoa harvest owned by farmers. Fermented beans will enhance the taste when processed cocoa beans.

\section{PENDAHULUAN}

Tanaman kakao merupakan tanaman tahunan yang berasal dari Amerika Selatan yang dibudidayakan pada daerah tropis. Kakao mulai di perkenalkan ke indonesia oleh bangsa Spanyol di Minahasa, Sulawesi Utara pada tahun 1560. Pada tahun 1825-1838 Indonesia telah mengekspor sebanyak 92 ton kakao dari pelabuhan Manado ke Philipina. Nilai ekspor itu di kabarkan telah menurun disebabkan adanya serangan hama pada tanaman kakao. Namun pada tahun 1919 Indonesia telah mampu mengekspor 30 ton kakao, tetapi pada tahun 1928 ekspor itu akhirnya terhenti. Pada tahun 1859 sudah terdapat 10.000-12.000 tanaman kakao di Ambon dan menghasilkan 11,6 ton kakao. Namun, tidak ada informasi lebih lanjut terhadap tanaman kakao tersebut. (Wahyudi et al., 2008).

Berdasarkan data Direktorat Jenderal Perkebunan bahwa sekitar 90 persen dari total produksi perkebunan kakao di Indonesia merupakan biji kakao yang belum difermentasi,
Cocoa beans that go through post-harvest processing will take longer to store and will not reduce the quality of the cocoa beans. Fermented cocoa beans contain water in them. which functions during fermentation for the enzyme reaction process in the beans and for microbial growth in the cocoa pulp. This post-harvest cocoa has a high selling value that will increase farmers' income. There are also in some areas forming farmer cooperatives so that the results of the farmers' harvest can be coordinated in one cooperative which results in clearer and controlled prices, because there are standards that have been set by farmers to sell wet cocoa beans, dry cocoa beans have not been fermented, dry cocoa beans are already fermented.

sedangkan harga ekspor biji kakao ditetapkan di pasar internasional berdasarkan biji kakao fermentasi (Ditjenbun, 2012).

Perkebunan kakao di Indonesia mengalami perkembangan pada tahun 2016 areal perkebunan kakao Indonesia tercatat seluas 1,72 juta ha. Menurut status pengusahaannya, sebagian besar perkebunan Kakao pada tahun 2016 diusahakan oleh perkebunan rakyat yaitu sebesar 1,68 juta hektar $(97,55 \%)$, sementara perkebunan swasta mengusahakan 27,34 ribu hektar $(1,59 \%)$ dan perkebunan besar negara hanya sebesar 14,79 ribu hektar (0,86 \%). Pada tahun 2017 perkebunan Kakao yang diusahakan oleh perkebunan rakyat diperkiraan sebesar 1,69 juta hektar $(97,84 \%)$, sementara perkebunan besar swasta mengusahakan 22,41 ribu hektar $(1,29$ \%) dan perkebunan besar negara hanya mengusahakan 17,74 ribu hektar $(0,85 \%$.) (BPS, 2017) Indonesia memiliki sentra perkebunan kakao yang tersebar di beberapa provinsi antara lain: Sulawesi (63,8\%), 
Sumatera (16,3\%), Jawa $(5,3 \%)$, Nusa Tenggara Timur, Nusa Tenggara Barat dan Bali (4,0\%), Kalimantan (3,6\%), Maluku dan Papua (7,1\%) (Ditjenbun, 2013).

Kakao Indonesia sebenarnya memiliki kualitas yang tidak kalah dengan hasil kakao pasar dunia apabila proses fermentasi dilakukan dengan baik oleh petani maka bukan tidak mungkin kakao indonesia dapat memiliki cita rasa yang sepadan dengan kakao dari Ghana. Apalagi kakao Indonesia memiliki keunggulan yaitu tidak mudah leleh sehingga cocok bila digunakan untuk blending. Terkait dengan kemampuan daya saing kakao indonesia tidak bisa dikesampingkan bahwasannya ditentukan faktor lokal daerah (Marzuki, Ervan, 2012). Sehingga dengan hal tersebut, maka peluang pasar kakao Indonesia terbuka lebar baik mencukupi pasar dalam negeri maupun mencukupi kebutuhan pasar internasional. Maka dapat disimpulkan bahwa, industri kakao memiliki potensi yang besar sebagai pendorong pertumbuhan ekonomi dan distribusi pendapatan dari petani maupun pemerintah. Walaupun seperti itu, usaha dibidang kakao Indonesia masih menghadapi berbagai masalah yang cukup banyak antara lain serangan hama penggerek buah kakao (PBK) yang mengakibatkan menurunya produktivitas kebun kakao, mutu produk masih rendah serta masih belum maksimalnya pengembangan produk hilir dari kakao. Hal ini menjadi suatu tantangan yang harus dijawab dari investor asing maupun local untuk mendapatkan keuntungan dan mengembangkan agar usaha dibidang kakao di Indonesia menjadi semakin maju (Departemen perindustrian. 2017).
Fermentasi biji kakao berfungsi untuk menghilangkan pulp dan sebagai bentuk daru sebuah reaksi kimia dan biokimia didalam keping biji. Penghancuran pulp ini berfungsi sebagai agar biji kakao cepat kering dan bersih, sedangkan reaksi kimia dan biokimia ini berfungsi sebagai prekursor aroma dan warna pada kakao. Proses fermentasi menyebabkan perubahan pada biji kakao, seperti: pulp terbuka, alkahol akan terbentuk karena fermentasi gula dalam di lapisan pulp , adanya kenaikan suhu, terjadi oksidasi oleh bakteri, terjadinya perubahan alkohol menjadi asam asetat, menyebabkan kematian biji, kehilangan daya berkecambah, terjadi difusi zat warna dari kantong sel, terjadi destruksi zat warna antosianin, terjadi pembentukan prekursor aroma dan warna. Perubahan agar dapat berhasil secara optimal, maka pulp sebagai media utama harus sesuai untuk pertumbuhan mikrobia. Pulp yang sesuai berasal dari buah kakao yang sehat dan masak optimum, sehingga pertumbuhan yeast dapat maksimal dikarenakan perbandingan kandungan gula dan asam (Hatmi dan Rustijarno, 2012) Menurut Sabahannur dkk (2016), Petani kakao sebagian besar petani kakao menggunakan alat yang sederhana sehingga biji rawan terkonntaninasi. Peningkatan kualitas biji kakao harus dimulai dari proses budidaya sampai dengan penanganan pascapanen, terutama pada proses fermentasi kakao, karena tanpa fermentasi biji kakao akan memiliki citarasa cokelat yang rendah serta lebih dominan pahit dan sepat, sehingga tidak disukai konsumen (Misnawi, 2008). 


\section{PEMBAHASAN}

\section{Pascapanen biji kakao}

Pascapanen merupakan salah satu aspek penting dalam penjualan hasil tanaman kakao. Harga jual biji kakao sangatlah beragam tergantung juga dari pengepul. Ada juga dibeberapa daerah membentuk koperasi petani sehingga hasil dari panen petani dapat di koordinir dalam satu koperasi yang menyebabkan harga yang terkontrol dan lebih jelas, karena ada standar yang sudah ditetapkan petani menjual dari biji kakao basah, biji kakao kering belum terfermentasi, biji kakao kering sudah terfermentasi.

Pengolahan pascapanen pada tanaman kakao untuk meningkatkan kualitas dari hasil panen kakao yang dimiliki oleh petani. Biji yang telah melalui fermentasi akan meningkatkan cita rasa ketika biji kakao diolah. Biji kakao yang melalui dalam proses pengolahan pascapanen akan lebih lama disimpan dan tidak akan mengurangi kualitas dari biji kakao. Biji kakao yang difermentasi mengandung air didalamnya. yang berfungsi selama fermentasi untuk proses reaksi enzima pada biji serta untuk pertumbuhan mikroba pada pulp kakao. (Ardhana, 2003).

Penanganan pasca panen sangat menentukan mutu hasil produksi biji kakao. Mutu biji kakao merupakan hal yang sangat penting dalam produksi kakao dan olahannya. Jika biji kakao bermutu rendah, produk olahannya akan buruk. Pengawasan mutu menjadi hal yang perlu diperhatikan, yakni dengan adanya inspeksi dan penerapan Good Manufacturing Practice (GMP). Prinsip GMP adalah untuk memantapkan mutu yang baik, mulai dari aspek bahan tanam, agronomi, prapanen, pascapanen, penggudangan, pengiriman, hingga produk akhir (Sugiharti, 2008).

Berikut adalah tahapan pascapanen

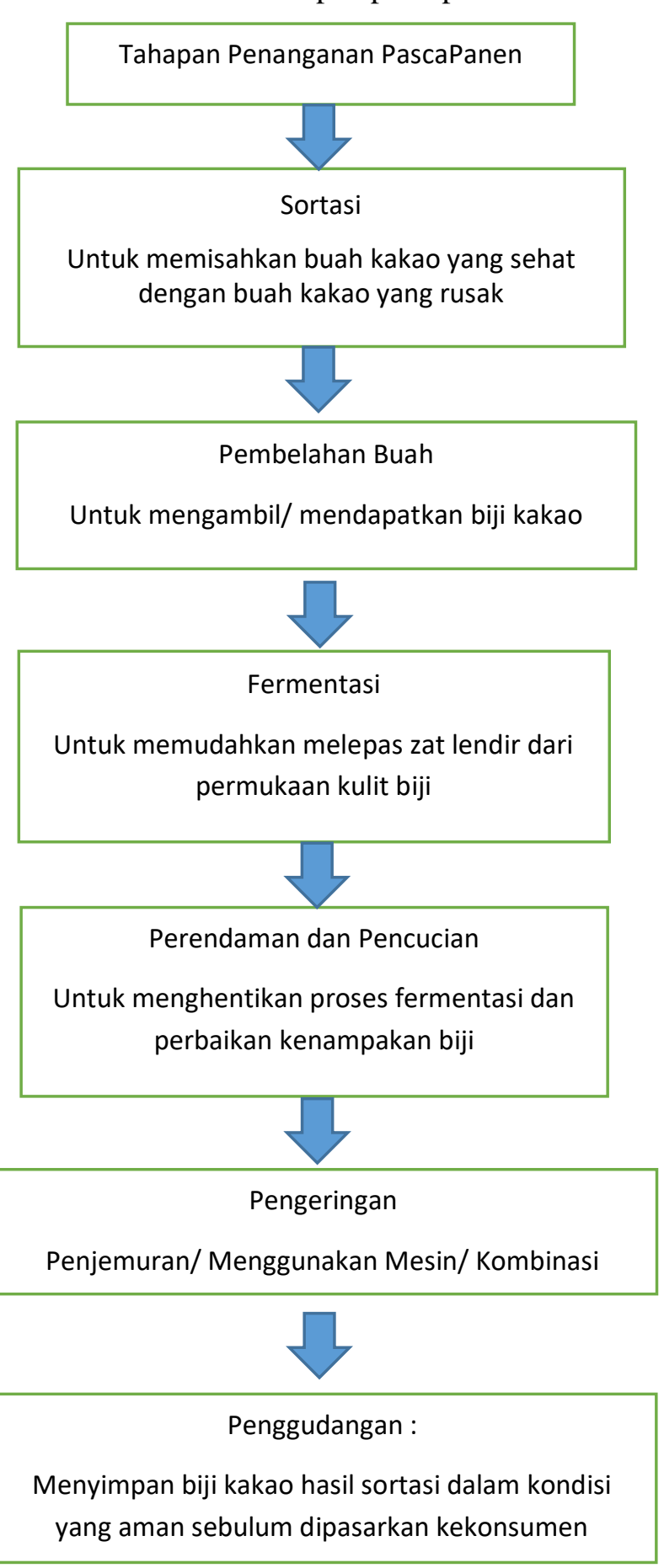

Sumber : dimodifikasi dari Maisbaitun 2015

\section{Pembelahan buah dan sortasi biji}

Pemecahan buah adalah suatu kegiatan mengeluarkan dan memisahkan biji kakao dari 
kulit buah dan plasentanya. Proses pemecahan buah ini dapat dilakukan secara manual dan mekanik (Maisbaitun 2015). Pembelahan buah kakao secara manual dengan alat pemukul, sabit, palu atausaling memukulkan buah mengakibatkan meningkatnya presentase biji kakao yang rusak semakin tinggi Rahman dkk, (2016).

\section{Fermentasi kakao}

Fermentasi merupakan salah satu proses untuk mendapatkan biji kakao kering yang memiliki kualitas baik dan memiliki aroma serta cita rasa (Karmawati, 2010). Fermentasi biji kakao merupakan proses yang paling vital dalam pasca panen biji kakao, karena pada tahapan tersebut akan terbentuk aroma khas coklat pada biji kakao. Fermentasi akan mempermudah pengeringan dan menghancurkan lapisan pulp melekat pada biji (Susanti, 2012)

Hernani et al., (2011) berpendapat bahwa, fermentasi biji kakao pasca rehidrasi tidak cukup mengandalkan proses dari seperti biji segar, tetapi juga memerlukan inokulum bakteri asam laktat. Fermentasi yang sudah terukur mampu mempercepat proses fermentasi yang mulanya 168 jam menjadi 120 jam (Munarso et al., 2016).

Fermentasi biasanya menggunakan kotak kayu dengan lubang didasarnya untuk membuang cairan fermentasi atau keluar masuknya udara. Biji diselimuti dengan daun pisang atau karung agar suhu tetap panas. Selanjutnya akan dilakukan pengadukan setiap hari atau dua hari selama waktu 6-8 hari. Fermentasi disarankan untuk tidak lebih 7 hari. Setelah difermentasi biji kakao segera dikeringkan (Karmawati, 2010). Selain peningkatan mutu, nilai tambah limbah dari biji fermentasi meiliki nilai ekonomi juga (Puastuti W. 2002). Menurut Guntoro dkk, (2005), bahwasanya limbah dari kakao fermentasi dapat digunakan sebagai pakan ayam buras petelur karena limbah fermentasi mengandung protein yang tinggi.

\section{Perendaman dan Pencucian}

Pencucian dilaksanakan setelah proses fermentasi berguna mengurangi pulp yang melekat pada biji. Biji direndam selama 3 jam untuk meningkatkan jumlah biji bulat dan penampilan menarik. Apabila menggunakan mesin kakao berkapasitas 2 ton biji segar/jam. Pencucian dimulai pukul 03.00 sampai pukul 10.00 sehingga kapasitas per hari adalah 14 ton (Karmawati, 2010).

\section{Pengeringan dan tempiring}

Pengeringan memiliki fungsi mengurangi kadar air biji yang awalnya $60 \%$ menjadi 6-7\% sehingga aman selama proses pengiriman dalam negeri maupun luar negeri. Penjemuran cara yang ideal adalah kapasitas per $\mathrm{m}^{2}$ lantai $15 \mathrm{~kg}$. Metode pengeringan ini memerlukan waktu 5 hingga 7 hari untuk mencapai kadar air di bawah 7,5\%. Kadar air biji kakao yang lebih dari 7,5\% tidak memenuhi persyaratan SNI (Hatmi dan Rustijarno, 2012).

Selain itu, pengeringan juga dapat dilakukan dengan menggunakan mesin karena cuaca tidak selalu cerah, hal ini dimaksudkan agar tidak terjadi kerusakan pada biji kakao fermentasi terhadap biji kakao, karena indeks fermentasi dapat mengukur perubahan warna yang terjadi pada biji selama fermentasi berlangsung (Iflah, 2016). 
Sidabariba (2017), uji variasi suhu pengeringan biji kakao dengan cabinet dryer menunjukkan hasil terbaik pada perlakuan dengan suhu $60^{\circ} \mathrm{C}$ selama 7 jam menghasilkan biji kakao dengan kadar air 3,13\%; kadar lemak $38,53 \%$; warna 2,97 (cokelat), dan aroma 1,57 (kurang disukai). Pengeringan dipengaruhi oleh suhu dan lama pengeringan. Suhu tinggi dapat mengakibatkan biji kakao hangus dengan kadar air serendah mungkin. Selain itu suhu yang terlalu tinggi akan berpengaruh pada $\mathrm{pH}$ yang dihasilkan. Jika suhu pengeringan tinggi maka kulit biji akan mengalami pengerasan sehingga asam volatil tidak dapat keluar melewati kulit biji yang mengeras (Hii et al., 2012).

\section{Penggudangan}

Merupakan tahap terakhir agar biji kakao dapat dijaga kualitasnya sebelum masuk kekonsumen. Penyimpanan biji kakao tidak boleh disimpan bersama-sama dengan bahan pangan yang lain karena akan mempengaruhi bau dari kakao itu sendiri (Maisbaitun 2015).

\section{KESIMPULAN DAN SARAN}

Pengolahan pascapanen pada tanaman kakao untuk meningkatkan kualitas dari hasil panen kakao yang dimiliki oleh petani. Biji yang telah melalui fermentasi akan meningkatkan cita rasa serta kualitas mutu biji kakao, ketika biji kakao diolah maka akan menghasilkan kakao yang bauk. Biji kakao yang melalui dalam proses pengolahan pascapanen akan lebih lama disimpan dan tidak akan mengurangi kualitas dari biji kakao.

\section{DAFTAR PUSTAKA}

Afrianto, E. (2008). Pengawasan Mutu Bahan/Produk Pangan Jilid II. Jakarta. Direktorat Pembinaan Sekolah
Menengah Kejuruan, Direktorat Jenderal Manajemen Pendidikan Dasar dan Menengah, Departemen Pendidikan Nasional.

Ardhana, M. M. \& Fleet, G. (2003). The Microbial Ecology of Cocoa Bean Fermentation in Indonesia. International Journal of Food Microbiology. 86 (2003) :87-99.

Badan Pusat Statistik. (2017). Stasistik Kakao Indonesia. Jakarta.

Biji Kakao 01-2323-2008. BPTP Yogyakarta.

Ditjenbun. (2012). Pedoman umum gerakan nasional peningkatan produksi dan mutu kakao. Kementan, Jakarta.

Ditjenbun. (2013). Pedoman teknis penanganan pasca panen tanaman kakao. Kementan, Jakarta.

Guntoro, Suprio, Yasa, \& M. Rai. (2005). Penggunanan limbah Kakao fermentasi untuk pakan Ayam Buras Petelur. Jurnal Pengkajian dan Pengembangan Teknologi Pertanian Vol. 8, No.2, Juli 2005. Balai Pengkajian Teknologi Pertanian Bali.

Hatmi, R.U. \& Rustijarno, S. (2012). Teknologi Pengolahan Biji Kakao Menuju SNI Biji Kakao $01-2323-2008 . \quad$ Balai Pengkajian Teknologi Pertanian (BPTP) Sleman. Yogyakarta.

Hernani, S. Yuliani, W. Haliza, S.I. Kailaku, \& D. Sumangat. (2011). Teknologi produksi starter mikroba untuk peningkatan mutu biji kakao di tingkat pedagang pengumpul. Laporan Hasil Penelitian. Balai Besar Penelitian dan Pengembangan Pascapanen Pertanian, Bogor.

Hii C.L., Abdul, R. R., Jinap, S., \& Che, M. Y.B. (2006). Quality of Cocoa Beans Dried Using a Direct Solar Dryer at Differment Loading. Jurnal of Science of Food anf Agriculture. (86); 1237-1243.

Iflah, T. T. (2016). Indeks Fermentasi sebagai Indikator Keberhasilan Fermentasi Pada Kakao Tipe Lindak dan Mulia. Sukabumi: Balai Penelitian Tanaman Industri dan Penyegar. 
Karnamawati, E., Zainal, Syakir, Joni, M., Ketut, A., \& Rubiyo. (2010). Budidaya dan Pascapanen Kakao. Bogor.

Marzuki, E. (2012). Sistem Inovasi Daerah (SIDa) Sumatera Selatan. Badan Litbang dan Inovasi Daerah Provinsi Sumatera Selatan, PT Raja Grafindo Persada, Jakarta.

Masbaitun, H., Septi, W., \& Siti, R.G., (2015).Teknologi Fermentasi Kakao Kualitas Kakao Kualitas Ekspor di Papua. Papua.

Misnawi. (2008). Physico-Chemical Changes During Cocoa Fermentation and Key Enzymes Involved. Review Penelitian Kopi dan Kakao, 47-64.

Munarso, S.J., K.T. Dewandari, \& I. Rahmawati. (2016). Pengaruh teknik dan waktu fermentasi terhadap mutu biji kakao (Theobroma cacao L). Laporan Hasil Penelitian 2015. Balai Besar Penelitian dan Pengembangan Pascapanen Pertanian, Bogor.

Puastuti, W. (2002). Pengolahan kotoran ternak dan kulit buah Kakao untuk mendukung integrasi Kakao-Ternak. Lokakarya Nasional Pengembangan Jejaring Litbang dan Pengkajian Sistem Integrasi Tanaman - Ternak. Balai Penelitian Ternak, Bogor.

Rahman, F., Darise, F., \& Djamalu, Y. (2016). Rancang bangun mesin pemecah buah kakao. Jurnal Teknologi Pertanian Gorongtalo (JTPG). 1(1): 95-104.

Sabahannur, N \& Subaedah. (2016). Kajian mutu biji Kakao petani di Kabupaten Luwu Timur, Soppeng dan Bulukumba. Jurnal Industri Hasil Perkebunan Vol. 11 No.2, Balai Besar Industri Hasil Perkebunan, Badan Penelitian dan Pengembangan Industri, Makassar.

Sekertaris jendral. (2007). Gambaran Sekilas Industri Kakao. Sekertariat Jendral, Jakarta.

Sidabariba, N.W., Ainun, R., \& Saipul, B.D. (2017). Uji Variasi Suhu Pengeringan Biji Kakao dengan Alat Pengering Tipe Kabinet Terhadap Mutu Bubuk Kakao. J.Rekayasa Pangan dan Pert. Vol. 5 (1) ; 192-195.
Sugiharti, E. (2008). Petunjuk Praktis Menanam Kakao. Binamuda Ciptakreasi. Yogyakarta.

Susanti, R. (2012). Analisis Senyawa Fenolik (43-65). Semarang: Universitas Diponegoro Press.

Wahyudi, T \& Pujiyanto. (2008). Panduan Lengkap Kakao. Penebar Swadaya, Jakarta. 